\title{
Development of Wholesale and Retail Trade, Repair of Motor Vehicles and Motorcycles Business in Rangpur Division
}

\section{Omar Faruque ${ }^{1 *}$, Md. Motiur Rahman²}

${ }^{1}$ Associate Professor, Department of Accounting and Information Systems, Begum Rokeya University, Rangpur, BANGLADESH

${ }^{2}$ Professor, Department of Management Studies, Begum Rokeya University, Rangpur, BANGLADESH

*Corresponding Contact:

Email: faruque1712@gmail.com

Accepted: 13 June 2021

\begin{abstract}
Bangladesh has already become a middle-income country. Yet its large number of working people is still jobless. The importance of Wholesale, Retail, Motor-vehicle workshop, and Motorcycle businesses (WRMB) for solving employment problems in a short time is immense. WRMB can pave the way for the employment of these people. There are eighteen types of manufacturing and service activity in the smallscale industry (SSI) sector. Out of this WRMB activity sector holds the height contribution in number. This paper attempts to discover the present situation of the Growth and Development of the Wholesale, Retail, Motor-vehicle workshops, and Motorcycle businesses in the Rangpur Division of Bangladesh during 2013-14 to 2017-18. The study is empirical. Both the primary and secondary data have been used in this study. Primary data is collected from 200 wholesale and retail trade, repair of motor vehicles, and motorcycles activity. The study found a simple correlation between financial conditions of the WRMB with the three dependent variables `net sales 2013-14', 'net sales 2017-18', and 'average net sales'.
\end{abstract}

Keywords: Cross-sectional Study, Small Scale Industry, Motor-vehicle Workshop, Motorcycle Business, Growth, Bangladesh

This article is is licensed under a Creative Commons Attribution-NonCommercial 4.0 International License. Attribution-NonCommercial (CC BY-NC) license lets others remix, tweak, and build upon work non-commercially, and although the new works must also acknowledge \& be non-commercial.

\section{INTRODUCTION}

Today's world is full of competition for wealth. The evil competition is constantly making the world sick and inhuman. The rich are getting richer, and the poor are getting poorer. Today, in a capitalist economy, the Vicious Cycle of poverty is the most extreme reality. In this situation, the small scale Industries (SSI) can now play an important role in sustaining the economically backward people of the society. The small scale Industries are taking the economy one step further every day on the path of balanced development. SSIs are 
making a significant contribution to the economic progress of the developed countries like Japan and the UK. There are 7818565 establishments in Bangladesh, out of which 3589443 are wholesale and Retail Trade, Repair of Motor Vehicles, and motorcycles business (WRMB), which is 45.90 percent of the total establishment.

The key objective of this study is to find out the present situation of the Growth and Development of Wholesale, Retail, Motor-vehicle Workshops and Motorcycle business in the Rangpur Division of Bangladesh during 2013-14 to 2017-18. The specific objectives of the study are as follows:

- To assess the relationship between demographic information with the growth and development of Wholesale, Retail, Motor-vehicle Workshops, and Motorcycle business.

- To assess the relationship between industry information with the growth and development of Wholesale, Retail, Motor-vehicle Workshops, and Motorcycle business.

- To assess the relationship between financial conditions with the growth and development of Wholesale, Retail, Motor-vehicle Workshops, and Motorcycle business.

\section{Statement of the Problem}

So, WRMB is a very important business sector in Bangladesh as well as in the Rangpur Division of Bangladesh. The importance of WRMBs for solving employment problems in a short time is immense. Bangladesh has already become a middle-income country. Yet its large number of working people is still jobless. WRMB can pave the way for the employment of these people. Out of eighteen types of manufacturing and service activity, it seems that WRMBs sector is more important as a number and as a contributor to the economy of Bangladesh. In the same way, table 1 shows that there are 111531 establishments in Bangladesh, out of which 55801 are WRMB, which is 50.03 percent of the total establishment.

Table 1: Activity-based total establishments in Rangpur Division, Bangladesh in 2013

\begin{tabular}{|c|c|c|c|c|c|c|c|c|c|c|}
\hline & & & & & Numbe & of Establ & shments & & & \\
\hline & Service Activity & Rangpur & Lalmonirhat & Gaibandha & Kurigram & Dinajpur & Panchagarh & Nilphamari & Thakurgone & Total \\
\hline $\mathrm{A}$ & $\begin{array}{l}\text { Mining and } \\
\text { Quarrying }\end{array}$ & 2 & 19 & 1 & 9 & 1 & 95 & 121 & 0 & 248 \\
\hline B & Manufacturing & 372 & 51 & 337 & 114 & 524 & 80 & 212 & 258 & 1948 \\
\hline C & $\begin{array}{l}\text { Electricity, Gas, } \\
\text { Steam and Air } \\
\text { Conditioning } \\
\text { Supply }\end{array}$ & 15 & 11 & 11 & 18 & 21 & 7 & 5 & 6 & 94 \\
\hline $\mathrm{D}$ & $\begin{array}{l}\text { Water Supply, } \\
\text { Sewerage, } \\
\text { Waste } \\
\text { Management } \\
\text { and } \\
\text { Remediation } \\
\text { Activities } \\
\end{array}$ & 3 & 2 & 0 & 1 & 2 & 0 & 2 & 0 & 10 \\
\hline E & Construction & 338 & 26 & 2 & 55 & 5 & 12 & 16 & 0 & 454 \\
\hline $\mathrm{F}$ & $\begin{array}{l}\text { Wholesale and } \\
\text { Retail Trade, } \\
\text { Repair of Motor } \\
\text { Vehicles and } \\
\text { Motorcycles }\end{array}$ & 19669 & 9009 & 444 & 273 & 706 & 2284 & 23174 & 242 & 55801 \\
\hline G & $\begin{array}{l}\text { Transportation } \\
\text { and Storage }\end{array}$ & 3811 & 15670 & 37 & 24 & 94 & 79 & 150 & 34 & 19899 \\
\hline
\end{tabular}




\begin{tabular}{|c|c|c|c|c|c|c|c|c|c|c|}
\hline $\mathrm{H}$ & $\begin{array}{l}\text { Accommodation } \\
\text { and Food } \\
\text { Service } \\
\text { Activities (Hotel } \\
\text { and Restaurant }\end{array}$ & 450 & 63 & 35 & 28 & 45 & 101 & 316 & 26 & 1064 \\
\hline I & $\begin{array}{l}\text { Information and } \\
\text { Communication }\end{array}$ & 211 & 39 & 51 & 38 & 67 & 23 & 75 & 13 & 517 \\
\hline $\mathrm{J}$ & $\begin{array}{l}\text { Financial and } \\
\text { Insurance } \\
\text { Activities }\end{array}$ & 572 & 205 & 366 & 262 & 590 & 165 & 323 & 199 & 2682 \\
\hline $\mathrm{K}$ & $\begin{array}{l}\text { Real Estate } \\
\text { Activities }\end{array}$ & 41 & 4 & 4 & 6 & 91 & 1 & 5 & 0 & 152 \\
\hline $\mathrm{L}$ & $\begin{array}{l}\text { Professional, } \\
\text { Scientific and } \\
\text { Technical } \\
\text { Activities } \\
\end{array}$ & 205 & 109 & 16 & 4 & 124 & 33 & 464 & 1 & 956 \\
\hline M & $\begin{array}{l}\text { Administrative } \\
\text { and Support } \\
\text { Service } \\
\text { Activities }\end{array}$ & 156 & 23 & 15 & 12 & 33 & 34 & 113 & 7 & 393 \\
\hline $\mathrm{N}$ & $\begin{array}{l}\text { Public } \\
\text { Administration } \\
\text { and Defense, } \\
\text { Compulsory } \\
\text { Social Security } \\
\end{array}$ & 170 & 83 & 94 & 130 & 241 & 114 & 120 & 99 & 1051 \\
\hline $\mathrm{O}$ & Education & 1826 & 805 & 1603 & 1301 & 2150 & 629 & 800 & 742 & 9856 \\
\hline $\mathrm{P}$ & $\begin{array}{l}\text { Human Health } \\
\text { and Social Work } \\
\text { Activities }\end{array}$ & 773 & 141 & 74 & 53 & 230 & 105 & 493 & 65 & 1934 \\
\hline $\mathrm{Q}$ & $\begin{array}{l}\text { Art, } \\
\text { Entertainment } \\
\text { and Recreation }\end{array}$ & 7 & 7 & 3 & 1 & 0 & 3 & 10 & 1 & 32 \\
\hline $\mathrm{R}$ & $\begin{array}{l}\text { Other Service } \\
\text { Activities }\end{array}$ & 5223 & 1828 & 136 & 223 & 255 & 331 & 6385 & 59 & 14440 \\
\hline S & Total & 33844 & 28095 & 3229 & 2552 & 5179 & 4096 & 32784 & 1752 & 111531 \\
\hline
\end{tabular}

Source: Bangladesh Economic Census Report 2013

\section{LITERATURE REVIEW}

Hosseini and Baiee (2012) aimed to identify the potential evaluation criteria of the plots proposed to the Mehr Imam Reza Fund. The study tried to create a proper basic framework, based on previous research, to carry out this experiment. The study suggested that one's attitude towards switching behavior, one's perceived control over switching costs, and perception of satisfaction with the service provider were strongly associated with one's intentions to switch additional services provided by producers.

Mtanga and McCamel (2019) examined the end markets and utilization of motorcycles, the status of these markets, and demand for local or regional production processes. The study also considered the main factors affecting the sales of motorcycles and their parts in the region and assesses whether a more coordinated approach between governments and foreign and local firms could lead to assembly and manufacturing value-added activity in the Southern African Development Community region.

Ogechukwu and Latinwo (2010) identifies the orientation of SMEs and entrepreneurial trends in Nigeria, tackles the operational definition and scopes, and describes the role of the Nigerian government as a participant, regulator, and facilitator, both legally and politically, in the growth of SMEs and entrepreneurship. The study also identifies the roles 
of SMEs in Nigeria's development and growth. Finally, they discussed the entrepreneurial thoughts, problems, and advance practical marketing solutions and concluded the role of marketing in the survival of SMEs and entrepreneurship in Nigeria.

Oppong et al. (2014) state that the financial constraints and lack of management skillhampers the efficient performance of micro and the small scale enterprises in Ghana. Finally they recommend that government and other non-governmental organization should regularly organize seminars for potential and actual small and medium enterprise operators on how to plan, organize, direct and control their businesses, and that micro, small and medium enterprises operators' should device effective marketing strategies and good management customers relations at all times.

Osotimehin et al. (2012) examine the challenges and prospects of micro and small scale enterprises development in Nigeria. They conducted the study in Lagos State, SouthWestern Nigeria, with the use of questionnaires and interviews to gather relevant data that was statistically analyzed. The study finds the phenomenal growth of small and medium enterprise in Nigeria is mainly due to the people's quest to be self-employed and not because it is easy to establish or manage.

Taiwo et al. (2012) investigate Small and Medium Enterprises as a veritable tool in Economic Growth and Development. A survey method was used to gather data from 200 $\mathrm{SME} /$ Entrepreneurial officers and Managers from five selected local governments in Nigeria. The study revealed that the most common constraints hindering small and medium scale business growth in Nigeria are lack of financial support, poor management, corruption, lack of training and experience, poor infrastructure, insufficient profits, and low demand for products and services.

Uwitonze and Heshmati (2016) attempted to study in detail the development of the service sector over the years in Rwanda's economy and empirically estimate its determinants using an econometric methodology. The empirical data was collected from 2011 to 2014 on 241 firms and establishments. The results are shown that, the factors that have contributed to the development of the service sector. These factors can be used in forming public policy to use the service sector as a vehicle for speeding up the shift from a low income to a middle-income state.

\section{Methodology}

The study is empirical. The Primary and secondary data have been used in the study. The primary data have been collected for 200 Wholesale, Retail, Motor-vehicle Workshops, and Motorcycle business. A questionnaire is used for collecting the data. The secondary data are collected from some publications, journals, books, and documents. Various statistical tools like Descriptive statistics, Chi-Square Test, Multiple Regression, and Trend Analysis, are used in this study. SPSS 16.0, IBM SSS Statistics and excel are also used to complete the analytical part.

\section{Findings AND Discussion}

\section{Gender and Age of the Owner}

The frequency of male employees is 196 with a percentage of $98.0 \%$, and female employees is 4 with a percentage of $2.0 \%$ which is said that a large number of male works in the small scale industry than a female that explained in Table 2. 
Table 2: Gender of the employee of WRMB

\begin{tabular}{|c|c|c|}
\hline Gender & Frequency & Percent \\
\hline Male & 196 & 98.0 \\
\hline Female & 4 & 2.0 \\
\hline Total & 200 & 100.0 \\
\hline
\end{tabular}

Source: Field survey

On the other hand, in Table 3, total of 200 respondents from this WRMB, highest 67 employees are from the age range 30-35 and then second-highest is 54 employees from the age range 35-40. And then 23, 22, 14, 10 and 4 employee is from the age range 40-45,50$55,55-60,45-50$, above 60 respectively.

Table3: Age of the employee of WRMB

\begin{tabular}{|c|c|c|}
\hline Age & Frequency & Percent \\
\hline$<30$ years & 6 & 3.0 \\
\hline $30-35$ & 67 & 33.5 \\
\hline $35-40$ & 54 & 27.0 \\
\hline $40-45$ & 23 & 11.5 \\
\hline $45-50$ & 10 & 5.0 \\
\hline $50-55$ & 22 & 11.0 \\
\hline $55-60$ & 14 & 7.0 \\
\hline$>60$ year & 4 & 2.0 \\
\hline Total & $\mathbf{2 0 0}$ & $\mathbf{1 0 0 . 0}$ \\
\hline
\end{tabular}

Source: Field survey

\section{Age of the Industry}

The age of the industry is classified in three ways that are unit age, registration age, and operation age are shown in Table 4. For unit age, the highest frequency lies in 5-10 years and it is 71 with a frequency of $35.5 \%$. Then the second-highest value lies in 10-15 years that is 68 , with a frequency of $34.0 \%$. Then respectively we get $31(15.5 \%), 13(6.5 \%), 7$ $(3.5 \%)$ and $5(2.5 \%)$ for the industry age range 15-20, 20-25, 25-30, 30-35 and above 35 .

For registration age, the highest age lies in 10-15 years, and it is 67 with a frequency of $33.5 \%$. Then the second-highest value lies in 5-10 years that is 64 with a frequency of $32.0 \%$. Then the respectively we get $16(8.0 \%), 27(13.5 \%), 11(5.5 \%), 5(2.5 \%)$ and $6(3.0 \%)$, 4 (2.0) for the registration age range below 5, 15-20, 20-25, 25-30, 30-35 and above 35.

Table 4: Industry unit information of the WRMB

\begin{tabular}{|c|c|c|c|c|c|c|c|c|c|}
\hline & $<5$ years & $\begin{array}{c}5-10 \\
\text { years }\end{array}$ & $\begin{array}{c}10-15 \\
\text { years }\end{array}$ & $\begin{array}{c}15-20 \\
\text { years }\end{array}$ & $\begin{array}{c}20-25 \\
\text { tears }\end{array}$ & $\begin{array}{c}25-30 \\
\text { years }\end{array}$ & $\begin{array}{c}30-35 \\
\text { years }\end{array}$ & $\begin{array}{c}>35 \\
\text { years }\end{array}$ \\
\hline \multirow{2}{*}{ Unit Age } & Frequency & - & 71 & 68 & 31 & 13 & 7 & 5 & 5 \\
\cline { 2 - 11 }$y$ & Percent & - & 35.5 & 34.0 & 15.5 & 6.5 & 3.5 & 2.5 & 2.5 \\
\hline $\begin{array}{c}\text { Registration } \\
\text { Age }\end{array}$ & Frequency & 16 & 64 & 67 & 27 & 11 & 5 & 6 & 4 \\
\cline { 2 - 12 } & Percent & 8.0 & 32.0 & 33.5 & 13.5 & 5.5 & 2.5 & 3.0 & 2.0 \\
\hline $\begin{array}{c}\text { Age of } \\
\text { Operation }\end{array}$ & Frequency & - & 70 & 67 & 34 & 11 & 8 & 5 & 5 \\
\cline { 2 - 12 }$y$
\end{tabular}

Source: Field survey 
For age of operation, the highest age lies in 5-10 years and it is 70 with a frequency of $35.0 \%$. Then the second highest value lies in 10-15 years that is 67 with a frequency of $33.5 \%$. Then respectively we get $34(17.0 \%), 11(5.5 \%), 8(4.0 \%)$ and $5(2.5 \%)$ for the operation age range 15-20, 20-25, 25-30, 30-35 and above 35.

\section{Working Population}

Table 5 includes the nature of the working population of the WRMB. The working population is divided into two groups that are management staff and the office staff. The following table shows that the management staff is less than 5 in 196 WRMBs, and 5 to 10 in 2 WRMBs. On the other hand, the number of the office staff is less than 5 in 197 industries with a percentage of $98.5 \%$ and 5 to 10 in 3 industries with a percentage of $1.5 \%$. No industry holds more than 10 either management or the office staff.

Table 5: Working population of the WRMB

\begin{tabular}{|c|c|c|c|c|}
\hline & & $<5$ & $5-10$ & $10-15$ \\
\hline \multirow{2}{*}{ Number of Management Staff } & Frequency & 198 & 2 & - \\
\cline { 2 - 5 } & Percent & 99.0 & 1.0 & - \\
\hline \multirow{2}{*}{ Number of Office Staff } & Frequency & 197 & 3 & - \\
\cline { 2 - 5 } & Percent & 98.5 & 1.5 & - \\
\hline
\end{tabular}

Source: Field survey

The survey also finds that out of 200 workers, 187 industries hold below 16 numbers of workers. On the other hand, $93.0 \%$ industry holds less than 16 skilled workers.

\section{The Financial Conditions of Retall and Wholesale, Motorcycle BUSINESSES AND MOTOR-VEHICLE WORKSHOP}

In the following table, it is observed that the changing percent of all variables that included in growth and development studies. For assets, $2.58 \%$ improvement occurs from 2013-14 to 2014-15, 7.03\% improvement is occurs from 2014-15 to 2015-16, 2.88\% improvement is occurs from $2015-16$ to $2016-17,3.20 \%$ improvement is occurs from 201617 to $2017-18$ and $16.57 \%$ improvement is occurs from $2013-14$ to $2017-18$. For fixed asset, $2.08 \%$ improvement is occurs from $2013-14$ to $2014-15$ and $1.50 \%$ decreasing is occurs from 2016-17 to $2017-18$

For Liability and Owner's equity, 1.79\% decreasing is occurs from 2013-14 to 2014-15, $5.31 \%$ improvement is occurs from $2014-15$ to $2015-16,5.38 \%$ improvement is occurs from $2015-16$ to $2016-17,2.76 \%$ decreasing is occurs from $2016-17$ to $2017-18$ and $12.04 \%$ improvement is occurs from 2013-14 to 2017-18.

For Owner's equity, $3.59 \%$ decreasing is occurs from 2013-14 to $2014-15,4.70 \%$ improvement is occurs from 2014- 15 to $2015-16,6.10 \%$ improvement is occurs from 201516 to $2016-17,2.27 \%$ decreasing is occurs from $2016-17$ to $2017-18$ and $9.53 \%$ improvement is occurs from 2013-14 to 2017-18. For short-term liability, $1.98 \%$ improvements is occurs from 2013-14 to 2014-15, and $0.60 \%$ improvement is occurs from 2016-17 to 2017-18. For long-term liability, $3.44 \%$ improvement is occurs from 2013-14 to 2014-15, 8.27\% improvement is occurs from $2016-17$ to $2017-18$ and $28.18 \%$ improvement is occurs from 2013-14 to 2017-18 
For net sales/ total revenue $0.10 \%$ improvement is occurs from $2013-14$ to $2017-18$. The total profit, $-3.93 \%$ decreases is occurs from $2013-14$ to $2014-15,0.15 \%$ improvement is occurs from $2016-17$ to $2017-18$ and $2.84 \%$ improvement is occurs from 2013-14 to 2017-18. For net profit, $0.37 \%$ improvement is occurs from $2013-14$ to $2014-15,0.11 \%$ improvement is occurs from $2016-17$ to $2017-18$ and $2.84 \%$ improvement is occurs from 2013-14 to 201718.

Table 6: Financial conditions of the WRMB

\begin{tabular}{|c|c|c|c|c|c|c|c|c|c|c|c|c|c|c|c|c|}
\hline \multirow[b]{2}{*}{ Clause } & \multicolumn{16}{|c|}{ Amount } \\
\hline & 2013-14 & 2014-15 & Frequency & Delta & 2015-16 & Frequency & Delta & 2016-17 & Frequency & Delta & 2017-18 & Frequency & Delta & Frequency & Delta & \begin{tabular}{|c|}
$\begin{array}{c}\text { Average of } \\
\text { the average }\end{array}$ \\
\end{tabular} \\
\hline A. Assets & 87.46 & 89.72 & 2.26 & 2.58 & 96.03 & 6.31 & 7.03 & 99.10 & 3.07 & 3.20 & 101.95 & 2.85 & 2.88 & 14.49 & 16.57 & 94.85 \\
\hline $\begin{array}{l}\text { a) Fixed } \\
\text { Assets }\end{array}$ & 35.58 & 36.32 & 0.74 & 2.08 & 38.43 & 2.11 & 5.80 & 38.42 & -0.01 & $0 . \overline{0}$ & 38.99 & 0.58 & 1.50 & 3.41 & 9.58 & 37.55 \\
\hline $\begin{array}{l}\text { b) Current } \\
\text { Assets }\end{array}$ & 51.88 & 53.40 & 1.52 & 2.92 & 57.60 & 4.20 & 7.87 & 60.68 & 3.08 & 5.35 & 62.96 & 2.28 & 3.76 & 11.08 & 21.36 & 57.31 \\
\hline $\begin{array}{l}\text { B. Liability } \\
\text { and Owner's } \\
\text { equity }\end{array}$ & 102.45 & 100.66 & -1.79 & -1.74 & 106.01 & 5.35 & 5.31 & 111.71 & 5.70 & 5.38 & 114.79 & 3.08 & 2.76 & 12.34 & 12.04 & 107.12 \\
\hline $\begin{array}{l}\text { a) Owner's } \\
\text { equity }\end{array}$ & 71.71 & 69.13 & -2.58 & -3.59 & 72.39 & 3.25 & 4.70 & 76.80 & 4.41 & 6.10 & 78.55 & 1.75 & 2.27 & 6.83 & 9.53 & 73.72 \\
\hline $\begin{array}{l}\text { b) Short-term } \\
\text { Liability }\end{array}$ & 18.36 & 18.72 & 0.36 & 1.98 & 19.14 & 0.41 & 2.21 & 20.25 & 1.11 & 5.82 & 20.37 & 0.12 & 0.60 & 2.01 & 10.97 & 19.37 \\
\hline $\begin{array}{l}\text { C) Long- } \\
\text { term liability }\end{array}$ & 12.38 & 12.81 & 0.43 & 3.44 & 14.49 & 1.68 & 13.12 & 14.66 & 0.17 & 1.17 & 15.87 & 1.21 & 8.27 & 3.49 & 28.18 & 14.04 \\
\hline $\begin{array}{l}\text { a) Net sales/ } \\
\text { total revenue }\end{array}$ & 174.27 & 176.36 & 2.10 & 1.20 & 169.19 & -7.17 & -4.06 & 173.09 & 3.90 & 2.31 & 174.44 & 1.35 & 0.78 & 0.18 & 0.10 & 173.47 \\
\hline b) Total profit & 94.28 & 90.57 & -3.71 & -3.93 & 91.58 & 1.01 & 1.12 & 91.86 & 0.29 & 0.31 & 92.00 & 0.13 & 0.15 & -2.28 & -2.42 & 92.06 \\
\hline c) Net profit & 19.54 & 19.61 & 0.07 & 0.37 & 20.03 & 0.42 & 2.12 & 20.07 & 0.04 & 0.22 & 20.09 & 0.02 & 0.11 & 0.55 & 2.84 & 19.87 \\
\hline Capacity unit & 583.72 & 585.29 & 1.57 & 0.27 & \begin{tabular}{|l|}
582.89 \\
\end{tabular} & -2.40 & -0.41 & 580.98 & -1.91 & -0.33 & 589.11 & 8.13 & 1.40 & 5.39 & 0.92 & 584.40 \\
\hline Capacity Taka & 203.00 & 175.71 & -27.29 & -13.44 & 178.90 & 3.19 & 1.81 & 180.74 & 1.85 & 1.03 & 191.15 & 10.40 & 5.76 & -11.85 & -5.84 & 185.90 \\
\hline $\begin{array}{l}\text { Achievement } \\
\text { unit }\end{array}$ & 333.80 & 340.47 & 6.67 & 2.00 & 328.18 & -12.29 & -3.61 & 332.91 & 4.73 & 1.44 & 334.69 & 1.78 & 0.54 & 0.89 & 0.27 & 334.01 \\
\hline $\begin{array}{l}\text { Achievement } \\
\text { Taka }\end{array}$ & 105.69 & 103.95 & -1.75 & -1.65 & 106.68 & 2.73 & 2.63 & 105.87 & -0.81 & $\overline{-}$ & 106.39 & 0.52 & 0.49 & 0.69 & 0.66 & 105.72 \\
\hline $\begin{array}{l}\text { E.VAT } \\
\text { Payment }\end{array}$ & 0.03 & 0.03 & 0.00 & 15.84 & 0.03 & 0.00 & $\begin{array}{c}- \\
11.54\end{array}$ & 0.03 & 0.00 & 2.42 & 0.03 & 0.00 & 5.90 & 0.00 & 11.14 & 0.03 \\
\hline $\begin{array}{l}\text { F. Income } \\
\text { Tax Payment }\end{array}$ & 0.07 & 0.07 & 0.00 & 0.00 & 0.07 & 0.00 & 0.98 & 0.07 & 0.00 & 0.97 & 0.07 & 0.00 & 0.00 & 0.00 & 1.96 & 0.07 \\
\hline $\begin{array}{l}\text { G. Interest } \\
\text { Payment }\end{array}$ & 3.73 & 3.82 & 0.09 & 2.45 & 3.91 & 0.08 & 2.22 & 4.15 & 0.24 & 6.06 & 4.19 & 0.04 & 1.02 & 0.46 & 12.21 & 3.96 \\
\hline $\begin{array}{l}\text { H. Number of } \\
\text { Employees }\end{array}$ & 5.57 & 5.57 & -0.01 & -0.09 & 5.66 & 0.09 & 1.57 & 5.64 & -0.02 & $\overline{-}-\overline{36}$ & 5.63 & -0.01 & 0.09 & 0.06 & 1.01 & 5.61 \\
\hline $\begin{array}{l}\text { I. Number of } \\
\text { product/ } \\
\text { service/ } \\
\text { program }\end{array}$ & 3.60 & 3.60 & 0.00 & 0.00 & 3.60 & 0.00 & 0.00 & 3.60 & 0.00 & 0.00 & 3.60 & 0.00 & 0.00 & 0.00 & 0.00 & 3.60 \\
\hline
\end{tabular}

Source: Field survey

\section{Relationship Between Growth and DeVelopment With the OWNer's INFORMATION, INDUSTRIAL UNIT INFORMATION AND ORGANIZATION'S FINANCIAL CONDITION}

\section{Chi-square test for owners' information}

The Chi-square test (Pearson Chi-square test) is conducted for five independent variables with three dependent variable 'net sales 2013-14', 'net sales 2017-18' and 'average net sales'. From Table 7, all variables give insignificant results at $\mathrm{p}$-value $>0.005$. So those variables are not important with the output of WRMB.

Table 7: Pearson Chi-square test (P-value)

\begin{tabular}{|c|c|c|c|}
\hline \multirow{2}{*}{ Variables } & \multicolumn{3}{|c|}{ Pearson Chi-square test (P-value) } \\
\cline { 2 - 4 } & Net sales 2013-14 & Net sales 2017-18 & Average \\
\hline Gender & No value & No value & No value \\
\hline Age & 0.220 & 0.150 & 0,391 \\
\hline Educational qualification & 0.492 & 0.584 & 0.851 \\
\hline Experience & 0.024 & 0.119 & 0.303 \\
\hline Parental background & 0,620 & 0.763 & 0.981 \\
\hline
\end{tabular}

Source: Field survey 


\section{Chi-square Test for Industry Unit Information}

Chi-square test (Pearson Chi-square test) is conducted by 23 independent variables with six dependent variables 'net sales 2013-14', 'net sales 2014-15', 'net sales 2015-16', 'net sales 2016-17', 'net sales 2017-18' and 'average net sales'. From table 8, the working population (office staff) is significant at p-value $<.005$ that indicated education qualification has a great impact on the small scale industry. Similarly, for total workers, workers (full-time), workers (male) also contains a significant result with a p-value $<.005$ and these variables also has a great impact on WRMB when 'net sales 2013-14' is dependent variables. But the skilled workers, semi-skilled workers, unskilled workers, part-time workers and hired workers do not have a significant result that means these variables are insignificant about the output of WRMB. For the net sales 2014-15, the office staff and skilled workers contain a significant result and those variables also impact WRMB when 'net sales 2014-15' is dependent variables. But the total workers, semi-skilled workers, unskilled workers, part-time workers, full-time workers, male workers and hired workers do not have a significant result that means these variables are insignificant. For 'net sales 2015-16' the office staff, total workers, skilled workers, unskilled workers, parttime workers, full-time workers, male workers, hired workers holds a significant result with a p-value <.005 and these variables also impact this business when 'net sales 2015-16' is dependent variables. But the semi-skilled workers do not give a significant result that means this variable is insignificant. For the 'net sales $2017-18$ 'the office staff, total workers, skilled workers, unskilled workers, part-time workers, full-time workers, male workers, hired workers holds a significant relationship with a p-value $<.005$ and these variables also impact this industry when 'net sales $2017-18^{\prime}$ is dependent variables. But the semi-skilled workers give no significant result that means this variable is insignificance. For 'net sales average', the office staff, skilled workers holds a significant result with $p$-value $<.005$ and these variables also have a great impact on this industry when 'net sales average' is dependent variables. But the total number of workers, semi-skilled workers, unskilled workers, part-time workers, full-time workers, male workers, female workers, and hired workers does not give a significant result that means these variables are insignificant to the net sales.

Table 8: Pearson Chi-square test (P-value)

\begin{tabular}{|c|c|c|c|c|c|c|}
\hline \multirow{2}{*}{ Variables } & \multicolumn{6}{|c|}{ Pearson Chi-square test (P-value) } \\
\cline { 2 - 7 } & $\begin{array}{c}\text { Net sales } \\
2013-14\end{array}$ & $\begin{array}{c}\text { Net sales } \\
2014-15\end{array}$ & $\begin{array}{c}\text { Net sales } \\
2015-16\end{array}$ & $\begin{array}{c}\text { Net sales } \\
2016-17\end{array}$ & $\begin{array}{c}\text { Net sales } \\
2017-18\end{array}$ & Average \\
\hline $\begin{array}{c}\text { Working population } \\
\text { (office staff) }\end{array}$ & 0.000 & 0.000 & 0.000 & 0.000 & 0.000 & 0.003 \\
\hline Workers (total numbers) & 0.004 & 0.015 & 0.000 & 0.000 & 0.000 & 0.016 \\
\hline Workers (skilled) & 0.016 & 0.001 & 0.000 & 0.000 & 0.000 & 0.005 \\
\hline Workers (semi-skilled) & 0.543 & 0.604 & 0.466 & 0.332 & 0.015 & 0.722 \\
\hline Workers (Unskilled) & 0.014 & 0.018 & 0.002 & 0.000 & 0.000 & 0.083 \\
\hline Workers(Full-time) & 0.003 & 0.012 & 0.000 & 0.000 & 0.000 & 0.012 \\
\hline Workers(Part-time) & 0.014 & 0.018 & 0.002 & 0.000 & 0.000 & 0.084 \\
\hline Workers (male) & 0.003 & 0.012 & 0.000 & 0.000 & 0.000 & 0.012 \\
\hline Workers (Hired) & 0.037 & 0.108 & 0.004 & 0.000 & 0.000 & 0.087 \\
\hline
\end{tabular}

Source: Field survey 


\section{Chi-square Test for Financial Condition}

In table 9, Chi-square test is conducted for the independent variable growth and development with three dependent variables. All variables show a significant relationship except VAT payment, Income Tax Payment, Number of products/ services/ programs. These three variables are not important for WRMB.

Table 9: Pearson Chi-square test (P-value) for growth and development

\begin{tabular}{|c|c|c|c|}
\hline \multirow[t]{2}{*}{ Clause } & \multicolumn{3}{|c|}{ Amount } \\
\hline & 2013-14 & $2017-18$ & Average \\
\hline A. Assets & 0.000 & 0.000 & 0.000 \\
\hline a) Fixed Assets & 0.000 & 0.000 & 0.000 \\
\hline b) Current Assets & 0.000 & 0.000 & 0.000 \\
\hline B. Liability and Owner's equity & 0.000 & 0.000 & 0.000 \\
\hline a) Owner's equity & 0.000 & 0.000 & 0.000 \\
\hline b) Short-term Liability & 0.000 & 0.000 & 0.000 \\
\hline c) Long-term liability & 0.000 & 0.000 & 0.000 \\
\hline \multicolumn{4}{|l|}{ C) Profit } \\
\hline a) Net sales/ total revenue & 0.000 & 0.000 & 0.000 \\
\hline b) Total profit & 0.000 & 0.000 & 0.000 \\
\hline c) Net profit & 0.000 & 0.000 & 0.000 \\
\hline \multicolumn{4}{|l|}{ D. production/ service/ trainee capacity } \\
\hline a) Capacity & 0.000 & 0.000 & 0.000 \\
\hline \begin{tabular}{l|l} 
Unit \\
\end{tabular} & 0.000 & 0.000 & 0.000 \\
\hline Taka & 0.000 & 0.000 & 0.000 \\
\hline b) Achievement & 0.000 & 0.000 & 0.000 \\
\hline \begin{tabular}{l|l} 
Unit \\
\cline { 2 - 2 }
\end{tabular} & 0.000 & 0.000 & 0.000 \\
\hline Taka & 0.000 & 0.000 & 0.000 \\
\hline E) VAT Payment & 0.175 & 0.046 & 0.116 \\
\hline F) Income Tax Payment & 0.070 & 0.129 & 0.065 \\
\hline G. Interest Payment & 0.000 & 0.000 & 0.000 \\
\hline H) Number of Employees & 0.000 & 0.000 & 0.000 \\
\hline I) Number of product/ service/ program & 0.663 & 0.305 & 0.445 \\
\hline
\end{tabular}

Source: Field survey

\section{Regression Analysis of WRMB for Owners Information with Net Sales 2013-14}

In table 10, the simple correlation is represented by R-value which indicates a weak positive correlation. The total variations of $3.0 \%$ in the dependent variables are indicated by $\mathrm{R}$ square. The $\mathrm{R}$ square value is also known as a goodness of fit test. So the $\mathrm{R}$ square of $3.0 \%$ is revealed that $3.0 \%$ of the data fit the regression of the WRMM Business model and the model is not so good by the result of $\mathrm{R}$ square.

Table 10: Regression analysis of WRMB for Owners Information with Net sales 2013-14

\begin{tabular}{|c|c|c|c|}
\hline $\mathrm{R}$ & R Square & Adjusted R Square & Std. Error of the Estimate \\
\hline $.173^{\mathrm{a}}$ & .030 & .010 & 104.07548 \\
\hline
\end{tabular}

Source: Field survey 
The following ANOVA table (Table 11) shows the p-value $=0.201$ which is greater than 0.005 that concluded as, overall the regression WRMB model statistically insignificantly predicts the independent variables.

Table 11: ANOVA table for Owners Information with Net sales 2013-14

\begin{tabular}{|c|c|c|c|c|c|}
\hline \multicolumn{7}{|c|}{ ANOVA $^{\mathbf{b}}$} \\
\hline Model & Sum of Squares & df & Mean Square & F & Sig. \\
\hline Regression & 65374.276 & 4 & 16343.569 & 1.509 & $.201^{\mathrm{a}}$ \\
\hline Residual & 2112182.671 & 195 & 10831.706 & & \\
\hline Total & 2177556.947 & 199 & & & \\
\hline
\end{tabular}

Source: Field survey

\section{Regression analysis of WRMB for Owners Information with Net sales 2017-18}

Table 12 shows the simple correlation which indicates a weak positive correlation. The total variation is $2.3 \%$ in the dependent variables is indicated by the $\mathrm{R}$ square. The $\mathrm{R}$ square value is also known as a goodness of fit test. So the $R$ squared of $2.3 \%$ is revealed that $2.3 \%$ of the data fit the regression WRMB model and the model is not so good by the result of $\mathrm{R}$ square.

Table 12: Regression analysis of WRMB for Owners Information with Net sales 2017-18

\begin{tabular}{|c|c|c|c|}
\hline $\mathrm{R}$ & R Square & Adjusted R Square & Std. Error of the Estimate \\
\hline $.151^{\mathrm{a}}$ & .023 & .003 & 104.47890 \\
\hline
\end{tabular}

Source: Field survey

The following ANOVA table (Table 13) shows the p-value $=0.340$ which is greater than 0.005 that concluded as overall the regression WRMB model statistically insignificantly predicts the independent variables.

Table 13: ANOVA table for Owners Information with Net sales 2017-18

\begin{tabular}{|c|c|c|c|c|c|}
\hline \multicolumn{7}{|c|}{ ANOVA $^{\mathbf{b}}$} \\
\hline Model & Sum of Squares & df & Mean Square & F & Sig. \\
\hline Regression & 49685.667 & 4 & 12421.417 & 1.138 & $.340^{\mathrm{a}}$ \\
\hline Residual & 2128588.734 & 195 & 10915.840 & & \\
\hline Total & 2178274.402 & 199 & & & \\
\hline
\end{tabular}

Source: Field survey

\section{Regression Analysis of WRMB for Owners Information with Average Net Sales}

The following table shows the simple correlation. Here the R-value indicates a weak positive correlation. The total variation $3.6 \%$ is indicated by $\mathrm{R}$ square. The $\mathrm{R}$ square value is also known as a goodness of fit test. The $\mathrm{R}$ squared of $3.6 \%$ reveals that $3.6 \%$ of the data fit the regression WRMB model and the model is not so good by the result of $R$ square.

Table 14: Regression analysis of WRMB for Owners Information with Average Net sales

\begin{tabular}{|c|c|c|c|}
\hline $\mathrm{R}$ & R Square & Adjusted R Square & Std. Error of the Estimate \\
\hline $.191^{\mathrm{a}}$ & .036 & .017 & 105.67745 \\
\hline
\end{tabular}

Source: Field survey 
The following ANOVA table (Table 15) shows $p$-value $=0.122$ which is greater than 0.005 that is concluded as the overall regression WRMB model statistically insignificantly predicts the independent variables.

Table 15: ANOVA table for Owners Information with Average Net sales

\begin{tabular}{|c|c|c|c|c|c|}
\hline \multicolumn{7}{|c|}{ ANOVA $^{\mathrm{b}}$} \\
\hline Model & Sum of Squares & df & Mean Square & F & Sig. \\
\hline Regression & 82357.706 & 4 & 20589.427 & 1.844 & $.122^{\mathrm{a}}$ \\
\hline Residual & 2177706.079 & 195 & 11167.723 & & \\
\hline Total & 2260063.786 & 199 & & & \\
\hline
\end{tabular}

Source: Field survey

\section{Regression analysis of WRMB for Industry Unit Information with Net sales 2013-14}

Simple correlation is represented in table 16 that shows the R-value which indicates a positive correlation. The total variation is $30.01 \%$ and the dependent variables are indicated by $\mathrm{R}$ square. The $\mathrm{R}$ square value is also known as a goodness of fit test. So the $\mathrm{R}$ square value reveals that $30.01 \%$ of the data fit the regression WRMB model and the model is not so good by $\mathrm{R}$ square.

Table 16: Regression analysis of WRMB for Industry Unit Information with Net sales 2013-14

\begin{tabular}{|c|c|c|c|}
\hline R & R Square & Adjusted R Square & Std. Error of the Estimate \\
\hline $.549^{\mathrm{a}}$ & .301 & .162 & 91.91138 \\
\hline
\end{tabular}

Source: Field survey

The following ANOVA table shows the $p$-value $=0.001$ which is less than 0.005 that is concluded as overall the WRMB regression model statistically which is significantly predicts the independent variables.

Table 17: ANOVA table for Industry Unit Information with Average Net sales 2013-14

\begin{tabular}{|c|c|c|c|c|c|}
\hline \multicolumn{7}{|c|}{ ANOVA $^{\mathbf{b}}$} \\
\hline Model & Sum of Squares & df & Mean Square & F & Sig. \\
\hline Regression & 604047.705 & 33 & 18304.476 & 2.167 & $.001^{\mathrm{a}}$ \\
\hline Residual & 1402318.559 & 166 & 8447.702 & & \\
\hline Total & 2006366.264 & 199 & & & \\
\hline
\end{tabular}

Source: Field survey

Table 18 Coefficient analysis shows the relationship between dependent and all independent variables.

The relationship: $Y=\alpha+\beta_{1} X_{1}+\beta_{2} X_{2}+\beta_{3} X_{3}+\ldots \ldots \ldots \ldots \ldots \ldots+\beta n X n+\varepsilon$

$\mathrm{Y}=138.774+27.690 \mathrm{X}_{1}+118.301 \mathrm{X}_{2}+(-6.067) \mathrm{X}_{3}+(-81.821) \mathrm{X}_{4}+132.280 \mathrm{X}_{5}+(-55.478) \mathrm{X}_{6}+$ $66.563 \mathrm{X}_{7}+(-76.047) \mathrm{X}_{8}+\varepsilon$

The above table shows that $\beta_{1}$ the office staff is 27.690 and the regression function of WRMB is $Y=138.774+27.690$. It expresses that WRMB can be improved by 27.690 the number of office staff. $\beta_{2}$ of efficiency skilled is 118.301 which implies WRMB can be improved 118.301 by efficiency skilled. $\beta_{3}$ of efficiency semi-Skilled is (-6.067) which implies WRMB can be 
decreased 6.067 by efficiency semi-skilled workers. $\beta_{4}$ of full-time workers is $(-81.821)$ which implies WRMB can be decreased by 81.821 by the full-time workers. $\beta_{5}$ of male workers is 132.280 which implies WRMB can be improved by 132.280 by the male workers. $\beta_{6}$ of female workers is (-55.478) which implies WRMB can be decreased 55.478 by female workers. $\beta_{7}$ of family members workers is 66.563 which implies WRMB can be improved 66.563 by family member workers. $\beta 8$ of hired family member workers is (-76.047) which implies WRMB can be decreased 76.047 by hired family member workers.

Table 18: Coefficient table for Industry Unit Information with Average Net sales 2013-14

\begin{tabular}{|c|c|c|c|c|c|}
\hline \multirow{2}{*}{ Model } & \multicolumn{2}{|c|}{$\begin{array}{c}\text { Unstandardized } \\
\text { Coefficients }\end{array}$} & $\begin{array}{c}\text { Standardized } \\
\text { Coefficients }\end{array}$ & \multirow{2}{*}{$\mathrm{t}$} & \multirow{2}{*}{ Sig. } \\
\cline { 2 - 5 } & $\mathrm{B}$ & Std. Error & Beta & & \\
\hline (Constant) & 138.774 & 179.279 & & .774 & .440 \\
\hline Working population Number of office staff & 27.690 & 76.071 & .034 & .364 & .716 \\
\hline Efficiency Skilled & 118.301 & 99.750 & .257 & 1.186 & .237 \\
\hline Efficiency semi-Skilled & -6.067 & 12.374 & -.036 & -.490 & .625 \\
\hline Workers Fulltime & -81.821 & 100.534 & -.160 & -.814 & .417 \\
\hline Workers male & 132.280 & 148.249 & .243 & .892 & .374 \\
\hline Workers Female & -55.478 & 53.454 & -.132 & -1.038 & .301 \\
\hline Workers family members & 66.563 & 64.439 & .170 & 1.033 & .303 \\
\hline Workers hired family members & -76.047 & 142.934 & -.157 & -.532 & .595 \\
\hline
\end{tabular}

Source: Field survey

\section{Regression analysis of WRMB for Industry Unit Information with Net sales 2017-18}

Simple correlation is represented by $\mathrm{R}$-value in table 19 , which indicates a weak positive correlation. The total variation is $13.5 \%$ in the dependent variables is indicated by $\mathrm{R}$ square. The $\mathrm{R}$ square value is also known as a goodness of fit test. So the R squared of $13.5 \%$ reveals that $13.5 \%$ of the data fit the regression model and the model is not so good by the result of $R$ square.

Table 19: Regression analysis of WRMB for Industry Unit Information with Net sales 2017-18

\begin{tabular}{|c|c|c|c|}
\hline $\mathrm{R}$ & R Square & Adjusted R Square & Std. Error of the Estimate \\
\hline $.368^{\mathrm{a}}$ & .135 & .059 & 101.48181 \\
\hline
\end{tabular}

Source: Field survey

Table 20 shows the ANOVA, gives $p$-value $=0.036$ which are greater than 0.005 that is concluded as, overall, the regression model statistically insignificantly predicts the independent variables.

Table 20: ANOVA table for Industry Unit Information with Average Net sales 2017-18

\begin{tabular}{|c|c|c|c|c|c|}
\hline \multicolumn{7}{|c|}{ ANOVA $^{\text {b }}$} \\
\hline Model & Sum of Squares & df & Mean Square & F & Sig. \\
\hline Regression & 293706.090 & 16 & 18356.631 & 1.782 & $.036^{\mathrm{a}}$ \\
\hline Residual & 1874337.660 & 182 & 10298.559 & & \\
\hline Total & 2168043.750 & 198 & & & \\
\hline
\end{tabular}

Source: Field survey 


\section{Regression analysis of WRMB for Industry Unit Information with Average Net Sales}

In table 21, simple correlation is represented by R-value which indicated a weak positive correlation. The total variation of $15.7 \%$ in the dependent variables are indicated by $\mathrm{R}$ square. The $\mathrm{R}$ square value is also known as a goodness of fit test. So the R square of $15.7 \%$ is revealed that $15.7 \%$ of the data fit the regression model and the model is not so good by the result of $\mathrm{R}$ squared.

Table 21: Regression analysis of WRMB for Industry Unit Information with Average Net sales

\begin{tabular}{|c|c|c|c|}
\hline R & R Square & Adjusted R Square & Std. Error of the Estimate \\
\hline $.396^{\mathrm{a}}$ & .157 & .082 & 102.16848 \\
\hline
\end{tabular}

Source: Field survey

The ANOVA table (Table 22) give $p$-value $=0.010$ which is greater than 0.005 concluded that overall, the regression model statistically insignificantly predicts the independent variables.

Table 22: ANOVA table for Industry Unit Information with Average Net sales 2017-18

\begin{tabular}{|c|c|c|c|c|c|}
\hline \multicolumn{7}{|c|}{ ANOVA $^{\mathrm{b}}$} \\
\hline Model & Sum of Squares & df & Mean Square & F & Sig. \\
\hline Regression & 352828.320 & 16 & 22051.770 & 2.113 & $.010^{\mathrm{a}}$ \\
\hline Residual & 1899788.425 & 182 & 10438.398 & & \\
\hline Total & 2252616.744 & 198 & & & \\
\hline
\end{tabular}

Source: Field survey

\section{Regression analysis of WRMB for financial condition with Net sales 2013-14}

In table 23, the simple correlation is represented by R-value which indicates a strong positive correlation. The total variation of $96.0 \%$ in the dependent variables are indicated by $\mathrm{R}$ square. The $\mathrm{R}$ square value is also known as a goodness of fit test. So the $\mathrm{R}$ square of $96.0 \%$ reveals that $96.0 \%$ of the data fit the WRMB regression model and the model is not so good by the result of $R$ square.

Table 23: Regression analysis of WRMB for financial conditions with Net sales 2013-14

\begin{tabular}{|c|c|c|c|}
\hline R & R Square & Adjusted R Square & Std. Error of the Estimate \\
\hline $.983^{\mathrm{a}}$ & .960 & .941 & 33.47143 \\
\hline
\end{tabular}

Source: Field survey

The following ANOVA table gives $p$-value $=0.000$ which is less than 0.005 that concludes as, overall, the WRMB regression model statistically significantly predicts the independent variables.

Table 24: ANOVA table for financial conditions with Average Net sales 2013-14

\begin{tabular}{|c|c|c|c|c|c|}
\hline \multicolumn{7}{|c|}{ ANOVA } \\
\hline Model & Sum of Squares & df & Mean Square & F & Sig. \\
\hline Regression & 515559.840 & 12 & 42963.320 & 38.349 & $.000^{\mathrm{a}}$ \\
\hline Residual & 17925.389 & 16 & 1120.337 & & \\
\hline Total & 533485.230 & 28 & & & \\
\hline
\end{tabular}

Source: Field survey 
In table 25, the coefficient analysis shows the relationship between dependent and all independent variables. The relationship:

$Y=\alpha+\beta_{1} X_{1}+\beta_{2} X_{2}+\beta_{3} X_{3}+\ldots \ldots \ldots \ldots \ldots \ldots+\beta_{n} X_{n}+\varepsilon$

$\mathrm{Y}\left(\right.$ Net sales 2013-14) $=-28.821+0.589 \mathrm{X}_{1}+.176 \mathrm{X}_{2}+(-0.183) \mathrm{X}_{3}+3.475 \mathrm{X}_{4}+(-1.433) \mathrm{X}_{5}+$ $1.232 \mathrm{X}_{6}+(-2.157) \mathrm{X}_{7}+0.123 \mathrm{X}_{8}+0.143 \mathrm{X}_{9}+(-0.111) \mathrm{X}_{10}+.215 \mathrm{X}_{11}+0.004 \mathrm{X}_{12}+\varepsilon$

Table below shows that $\beta_{1}$ of fixed assets $2013-14$ is 0.589 and the regression function of WRMB is $Y$ (Net sales 2013-14) $=-28.821+0.589$. It expresses WRMB can be improved by 0.589 fixed assets 2013-14. $\beta_{2}$ of current assets 2013-14 is (0.176) which implies WRMB can be improved 0.176 by current assets $2013-14$. $\beta_{3}$ of equity 2013-14 is (-.183) which implies WRMB can be decreased .183 by equity 2013-14. $\beta_{4}$ of short-term liabilities 13 is (3.475) which implies WRMB can be improved by 3.475 by the short-term liabilities 2013-14. $\beta_{5}$ of long-term liabilities 2013-14 is (-1.433) which implies WRMB can be decreased 1.433 by long-term liabilities. $\beta_{6}$ of total profit $2013-14$ is 1.232 which implies WRMB can be improved 1.232 by total profit $2013-14$. $\beta_{7}$ of net profit $2013-14$ is $(-2.157)$ which implies WRMB can be decreased 2.157 by net profit 2013-14. $\beta 8$ of capacity quantity 2013-14 is 0.123 which implies WRMB can be improved 0.123 by capacity quantity 2013-14. $\beta_{9}$ of capacity taka $2013-14$ is 0.143 which implies WRMB can be improved 0.143 by capacity quantity 2013-14.

$\beta_{10}$ of achievement 2013-14 is (-.111) which implies WRMB can be decreased .111 by achievement 2013-14. $\beta_{11}$ of interest 2013-14 is .215 which implies WRMB can be improved .215 by interest $2013-14$. $\beta_{12}$ of workers $2013-14$ is 0.004 which implies WRMB can be improved 0.004 by workers 2013-14.

Table 25: Coefficient table for financial conditions with Average Net sales 2013-14

\begin{tabular}{|c|c|c|c|c|c|}
\hline \multicolumn{6}{|c|}{ Coefficients $^{a}$} \\
\hline \multirow{2}{*}{ Model } & \multicolumn{2}{|c|}{ Unstandardized Coefficients } & \multirow{2}{*}{\begin{tabular}{|c|} 
Standardized Coefficients \\
Beta
\end{tabular}} & \multirow{2}{*}{$\mathrm{t}$} & \multirow{2}{*}{ Sig. } \\
\hline & B & Std. Error & & & \\
\hline (Constant) & -28.821 & 21.751 & & -1.325 & .204 \\
\hline Fixed assets & .589 & .359 & .242 & 1.644 & .120 \\
\hline Current assets & .176 & .403 & .059 & .438 & .668 \\
\hline Equity & -.183 & .129 & -.136 & -1.414 & .177 \\
\hline Short-term liabilities & 3.475 & 1.134 & .266 & 3.063 & .007 \\
\hline Long-term liabilities & -1.433 & .928 & -.099 & -1.545 & .142 \\
\hline Total profit & 1.232 & .252 & .751 & 4.887 & .000 \\
\hline Net profit & -2.157 & 1.143 & -.261 & -1.887 & .077 \\
\hline Capacity quantity & .123 & .059 & .317 & 2.070 & .055 \\
\hline Capacity taka & .143 & .256 & .133 & .561 & .583 \\
\hline Achievement & -.111 & .090 & -.196 & -1.234 & .235 \\
\hline Interest & .215 & .115 & .160 & 1.867 & .080 \\
\hline Workers & -.004 & 3.859 & .000 & -.001 & .999 \\
\hline
\end{tabular}

Source: Field survey 


\section{Regression analysis of WRMB for the financial condition with Net sales 2017-18}

In the following table the simple correlation is represented by R-value which indicated a strong positive correlation. The total variation $98.4 \%$ in the dependent variables is indicated by $\mathrm{R}$ square. The $\mathrm{R}$ square value is also known as a goodness of fit test. So the $\mathrm{R}$ square of $98.4 \%$ reveals that $98.4 \%$ of the data fit the WRMB regression model and the model is not so good by the result of $\mathrm{R}$ square.

Table 26: Regression analysis of WRMB for financial conditions with Net sales 2017-18

\begin{tabular}{|c|c|c|c|}
\hline R & R Square & Adjusted R Square & Std. Error of the Estimate \\
\hline $.990^{\mathrm{a}}$ & .984 & .962 & 27.01039 \\
\hline
\end{tabular}

Source: Field survey

The following ANOVA table gives p-value $=0.000$ which is less than 0.005 that is concluded as, Overall, the WRMB regression model statistically significantly predicts the independent variables.

Table 27: ANOVA table for financial conditions with Average Net sales 2017-18

\begin{tabular}{|c|c|c|c|c|c|}
\hline \multicolumn{7}{|c|}{ ANOVA $^{\text {b }}$} \\
\hline Model & Sum of Squares & df & Mean Square & F & Sig. \\
\hline Regression & 533078.434 & 13 & 41006.033 & 56.206 & $.000^{\mathrm{a}}$ \\
\hline Residual & 10943.420 & 15 & 729.561 & & \\
\hline Total & 544021.853 & 28 & & & \\
\hline
\end{tabular}

Source: Field survey

Table 28 shows the coefficient relationship between dependent and all independent variables. The relationship:

$Y=\alpha+\beta_{1} X_{1}+\beta_{2} X_{2}+\beta_{3} X_{3}+\ldots \ldots \ldots \ldots \ldots \ldots+\beta n X n+\varepsilon$

$Y\left(\right.$ Net sales 2017-18) $=-18.459+2.109 X_{1}+1.989 X_{2}+(-1.364) X_{3}+(-.965) X_{4}+(-1.898) X_{5}+$ $.731 X_{6}+(.076) X_{7}+0.182 X_{8}+0.079 X_{9}+(-0.229) X_{10}+3.474 X_{11}+(-1.338) X_{12}+\varepsilon$

The following table shows that $\beta_{1}$ of fixed assets $2017-18$ is 2.109 and regression function of WRMB is $Y$ (Net sales 2017-18) $=-18.459+2.109$. It expresses that WRMB can be improved by 2.109 fixed assets $2017-18$. $\beta_{2}$ of current assets $2017-18$ is 1.989 which implies WRMB can be improved 1.989 by current assets $2017-18$. $\beta_{3}$ of equity $2017-18$ is $(-1.364)$ which implies WRMB can be decreased (-1.364) by equity 2017-18. $\beta_{4}$ of short-term liabilities 17 is (-.965) which implies WRMB can be decreased (-.965) by short-term liabilities 2017-18. $\beta_{5}$ of longterm liabilities 2017-18 is (-1.898) which implies WRMB can be decreased (-1.898) by longterm liabilities $2017-18$. $\beta_{6}$ of total profit $2017-18$ is .731 which implies WRMB can be improved .731 by total profit 2017-18. $\beta_{7}$ of net profit 2017-18 is (.076) which implies WRMB can be improved (.076) by net profit 2017-18. $\beta_{8}$ of capacity quantity 2017-18 is 0.182 which implies WRMB can be improved 0.182 by capacity quantity 2017-18 $\beta_{9}$ of capacity taka $2017-18$ is 0.079 which implies WRMB can be improved 0.079 by capacity quantity 2017-18. $\beta_{10}$ of Achievement 2017-18 is (-0.229) which implies WRMB can be decreased 0.229 by achievement $2017-18$. $\beta_{11}$ of interest $2017-18$ is 3.474 which implies WRMB can be improved 3.474 by interest 2017-18. $\beta_{12}$ of workers $2017-18$ is $(-1.338)$ which implies WRMB can be decreased (1.338) by workers 2017-18. 
Table 28: Coefficient table for financial conditions with Net sales 2017-18

\begin{tabular}{|c|c|c|c|c|c|}
\hline \multirow{2}{*}{ Model } & \multicolumn{7}{|c|}{$\begin{array}{c}\text { Unstandardized } \\
\text { Coefficients }\end{array}$} & Standardized Coefficients & \multirow{2}{*}{$\mathrm{t}$} & \multirow{2}{*}{ Sig. } \\
\cline { 2 - 6 } & $\mathrm{B}$ & Std. Error & Beta & \\
\hline (Constant) & -18.459 & 15.021 & & -1.229 & .238 \\
\hline Fixed assets & 2.109 & 1.481 & .894 & 1.424 & .175 \\
\hline Current assets & 1.989 & 1.566 & .679 & 1.270 & .223 \\
\hline Equity & -1.364 & 1.366 & -.669 & -.998 & .334 \\
\hline Short-term liabilities & -.965 & 2.811 & -.077 & -.343 & .736 \\
\hline Long-term liabilities & -1.898 & 2.028 & -.187 & -.936 & .364 \\
\hline Total profit & .731 & .221 & .443 & 3.310 & .005 \\
\hline Net profit & .076 & 1.255 & .009 & .060 & .953 \\
\hline Capacity quantity & .182 & .039 & .478 & 4.666 & .000 \\
\hline Capacity taka & .079 & .080 & .094 & .996 & .335 \\
\hline Achievement & -.229 & .083 & -.348 & -2.757 & .015 \\
\hline Interest & 3.474 & 7.904 & .068 & .440 & .667 \\
\hline Workers & -1.338 & 2.667 & -.030 & -.502 & .623 \\
\hline
\end{tabular}

Source: Field survey

\section{Regression analysis of WRMB for financial condition with Average Net Sales}

Table 29 shows the simple correlation presented by R-value (Table 18), which indicates a strong positive correlation. The total variation is $84.0 \%$ in the dependent variables is indicated by $\mathrm{R}$ square. The $\mathrm{R}$ square value is also known as a goodness of fit test. So the $\mathrm{R}$ square of $84.0 \%$ reveals that $84.0 \%$ of the data fit the regression model and the model is not so good by the result of $\mathrm{R}$ square.

Table 29: Regression analysis of WRMB for financial conditions with Average Net sales

\begin{tabular}{|c|c|c|c|}
\hline $\mathrm{R}$ & R Square & Adjusted R Square & Std. Error of the Estimate \\
\hline $.917^{\mathrm{a}}$ & .840 & .701 & 86.04087 \\
\hline
\end{tabular}

Source: Field survey

The following ANOVA table give $p$-value $=0.001$ which is less than 0.005 that is concluded as, overall, the regression model statistically significantly predicts the independent variables.

Table 30: ANOVA table for financial conditions with Average Net sales

\begin{tabular}{|c|c|c|c|c|c|}
\hline \multicolumn{7}{|c|}{ ANOVA $^{\mathbf{b}}$} \\
\hline Model & Sum of Squares & df & Mean Square & F & Sig. \\
\hline Regression & 583271.515 & 13 & 44867.040 & 6.061 & $.001^{\mathrm{a}}$ \\
\hline Residual & 111045.462 & 15 & 7403.031 & & \\
\hline Total & 694316.977 & 28 & & & \\
\hline
\end{tabular}

Source: Field survey 
Table 31 shows the coefficient relationship between dependent and all independent variables. The relationship: $Y=\alpha+\beta_{1} X_{1}+\beta_{2} X_{2}+\beta_{3} X_{3}+\ldots \ldots \ldots \ldots \ldots \ldots+\beta n X n+\varepsilon$

$Y($ Net sales Average $)=16.651+(-3.045) X_{1}+(-4.305) X_{2}+3.169 X_{3}+9.430 X_{4}+1.739 X_{5}+$ $1.642 X_{6}+(-2.596) X_{7}+0.245 X_{8}+0.439 X_{9}+(-0.413) X_{10}+(-8.331) X_{11}+1.834 X_{12}+\varepsilon$

The following table shows that $\beta_{1}$ of average fixed assets is $(-3.045)$ and regression function of WRMB is Y (Net sales Average $)=16.651+(-3.045)$. It is expressed that WRMB can be decreased by 3.045 fixed assets. $\beta_{2}$ of current assets is (-4.305) which implies WRMB can be decreased 4.305 by current assets. $\beta_{3}$ of equity is 3.169 which implies WRMB can be improved 3.169 by equity. $\beta_{4}$ of short-term liabilities is 9.430 which implies WRMB can be improved 9.430 by short-term liabilities. $\beta_{5}$ of long-term liabilities is 1.739 which implies WRMB can be improved 1.739 by long-term liabilities. $\beta_{6}$ of total profit is 1.642 which implies WRMB can be improved 1.642 by total profit. $\beta_{7}$ of net profit is $(-2.596)$ which implies WRMB can be decreased by 2.596 by net profit. $\beta_{8}$ of capacity quantity is 0.245 which implies WRMB can be improved 0.245 by capacity quantity. $\beta_{9}$ of capacity taka is 0.439 which implies WRMB can be improved 0.439 by capacity quantity. $\beta_{10}$ of Achievement is $(-0.413)$ which implies WRMB can be decreased 0.413 by Achievement. $\beta_{11}$ of Interest is (-8.331) which implies WRMB can be decreased 8.331 by Interest . $\beta 12$ of Workers is 1.834 which implies WRMB can be improved 1.834 by Workers.

Table 31: Coefficient table for financial conditions with Average Net sales

\begin{tabular}{|c|c|c|c|c|c|}
\hline \multirow{2}{*}{ Model } & \multicolumn{7}{|c|}{ Coefficients $^{\mathbf{a}}$} \\
& Constandardized & \multicolumn{2}{c|}{$\begin{array}{c}\text { Standardized } \\
\text { Coefficients }\end{array}$} & \multirow{2}{*}{$\mathrm{t}$} & \multirow{2}{*}{ Sig. } \\
\cline { 2 - 5 } & $\mathrm{B}$ & Std. Error & Beta & & \\
\hline (Constant) & 16.651 & 47.850 & & .348 & .733 \\
\hline Fixed assets & -3.045 & 4.718 & -1.142 & -.645 & .528 \\
\hline Current assets & -4.305 & 4.988 & -1.300 & -.863 & .402 \\
\hline Equity & 3.169 & 4.353 & 1.377 & .728 & .478 \\
\hline Short-term liabilities & 9.430 & 8.955 & .667 & 1.053 & .309 \\
\hline Long-term liabilities & 1.739 & 6.461 & .151 & .269 & .791 \\
\hline Total profit & 1.642 & .704 & .879 & 2.333 & .034 \\
\hline Net profit & -2.596 & 3.997 & -.282 & -.649 & .526 \\
\hline Capacity quantity & .245 & .124 & .571 & 1.978 & .067 \\
\hline Capacity taka & .439 & .254 & .459 & 1.732 & .104 \\
\hline Achievement & -.413 & .265 & -.555 & -1.557 & .140 \\
\hline Interest & -8.331 & 25.178 & -.145 & -.331 & .745 \\
\hline Workers & 1.834 & 8.495 & .036 & .216 & .832 \\
\hline
\end{tabular}

Source: Field survey

\section{CONCLUSION}

This study discussed the growth and development of WRMB, which is the most important part of the small scale industry of Bangladesh. The study attempted to find out the relationship between sales and other variables of this business sector. Finally, it is 
observed that the assets of WRMB is increased by $12.04 \%$ from 2013-14 to 2017-18. On the other hand, the net sales are increased by $0.10 \%$ from $2013-14$ to $2017-18$, and the total profit is increased by $2.84 \%$ at the mentioned period. The study found a simple correlation between financial conditions of the WRMB with the three dependent variables 'net sales 2013-14', 'net sales 2017-18', and 'average net sales'. The result indicates that education qualification has a great impact on WRMB. Similarly, for total workers, full-time workers, male workers also hold a great impact on WRMB's output. Assets, liability, and profit show a significant relationship with the sales volume of the business. A simple correlation between the financial position and sales revenue is found in this study.

\section{REFERENCES}

Bangladesh Bureau of Statistics (BBS) (2013). Report on Economic Census 2013. Dhaka: Reproduction, Documentation \& Publication (RDP) Section Bangladesh Bureau of Statistics. Retrieved from http://bbs.portal.gov.bd/sites/default/files/files/bbs.portal.gov.bd/page/f2661853 b857 49c5 8761 e1641e3aec9b/Pre Report Econo Cen 13.pdf

Bangladesh Bureau of Statistics (BBS) (2017). Bangladesh Economic Review 2017. Dhaka, Bangladesh. Retrieved from https://mof.gov.bd/site/page/44e399b3-d378-41aa-86ff8c4277eb0990/BangladeshEconomicReview

Faruque, O., \& Siddiqua, A. (2019). Challenges and Opportunities of Grocery Business: A Study on Rangpur City Corporation in Bangladesh. Global Disclosure of Economics and Business, 8(1), 49-60. https://doi.org/10.18034/gdeb.v8i1.97

Hosseini, S. M. \& Baiee, M. J. G. (2012). Designing a Decision-Maker Expert System for Evaluating the Business Potential of Proposed Plots to Mehr Imam Reza Fund. ZENITH International Journal of Business Economics \& Management Research, 2(5).

Mtanga, S. \& McCamel, R. (2019). Motorcycle Parts and Aftermarket Industry Regional Value Chain in Southern Africa, WIDER Working Paper 2019/38. https://doi.org/10.35188/UNUWIDER/2019/672-2

Ogechukwu, A. D. \& Latinwo, H. K. (2010). Entrepreneurial Developments and Small Scale Industry Contribution to Nigerian National development- A marketing Interface. Information Management and Business Review, 1(2), 51-68.

Oppong, M. \& Owiredu, A. \& Churchill, R. Q. (2014). Micro and Small Scale Enterprises Development in Ghana. European Journal of Accounting Auditing and Finance Research, 2(6), 78-91.

Osotimehin, K. O. \& Jegede, C. A \& Akinlabi, B. H. (2012). An Evaluation of the Challenges and Prospects of Micro and Small Scale Enterprises Development in Nigeria. American International Journal of Contemporary Research, 2(4).

Rahman, M. M., Rahman, M. M., \& Faruque, O. (2010). Problems and Prospects of Hosiery Industries of Pabna Distict. Banglavision, 1(1).

Taiwo, M., Ayodeji, A. \& Yusuf, B. (2012). Impact of Small and Medium Enterprises on Economic Growth and Development. American Journal of Business and Management, 1(1), 18-22.

Uwitonze, E. \& Heshmati, A. (2016). Service Sector Development and its Determinants in Rwanda, Forschungsinstitut zur Zukunft der Arbeit Institute for the Study of Labor, IZA Discussion Paper No. 10117

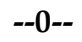

